\title{
Original
}

\section{Ochroconis Species Isolated from Limestone Areas as the Origin of Indoor Ochroconis}

\author{
NOBUO HAMADA ${ }^{1 *}$, AND NIICHIRO ABE $^{2}$ \\ ${ }^{1}$ Osaka Museum of Natural History, 1-23 Nagai Park, Higashi-Sumiyoshi, Osaka 546-0034, Japan \\ ${ }^{2}$ Osaka Institute of Public Health, 8-34 Tojo-cho, Tennoji, Osaka 543-0026, Japan
}

Received 7 May, 2019/Accepted 5 July, 2019

\begin{abstract}
The molecular, morphological, and physiological features of 42 strains of Ochroconis collected from many limestone areas were studied. Ochroconis strains are often found in limestone areas, although they have rarely been found in other wild areas, e. g. forests. Moreover, many strains from these areas grew on alkaline media (pH 9.7) and media with soap. They were phylogenetically more variable than Ochroconis strains previously found indoors or at city parks. Thus, the Ochroconis strains are thought to have adapted to the alkaline soil, specifically found in limestones. It is assumed that some strains of Ochroconis originally grew in the limestones and immigrated into park soils with the fine dust of cement and into indoor environments. More species of Ochroconis, with the ability to use surfactants as nutrients, are distributed in limestone areas than indoors or in city parks. Moreover, these fungi were found randomly in the phylogenetic trees of Ochroconis. Although only O. humicola was often found indoors and used surfactants, this fungus was newly found in the limestone areas of Okinawa Prefecture. Ochroconis humicola originally grew outdoors and seems to have immigrated to and propagated indoors. Thus, this species may have originated from the subtropical limestone areas.
\end{abstract}

Key words : Alkaline condition / Detergent / Drought / Heat tolerance / Limestone.

\section{INTRODUCTION}

Some unique fungi, using detergents as nutrients, have been found in water supply environments (Hamada, 2002; Hamada and Abe, 2009). Previous studies showed that Ochroconis humicola, using non-ion surfactants as nutrients, was predominantly found in indoor environments (Abe and Hamada, 2011) and distributed across Asia, Europe, and USA. Ochroconis humicola may not have grown indoors until about 50 years ago, when the custom of using detergents in the water supply began (JSWE, 2000).

Since these fungi may have immigrated from specific outdoor environments, we examined environments where 0 . humicola may have grown originally. We tried to collect Ochroconis strains from rural outdoor environments, such as mountains, forests, and agricultural

*Corresponding author. Tel: +81-90-7757-1087, Fax: +81-66697-6225, E-mail : mxi00715(a)nifty.com fields. However, it was difficult to collect not only $O$. humicola, but also some other species of Ochroconis (Hamada and Abe, 2018). Some strains of Ochroconis were found in the superficial soils of urban city parks, on which the fine dust of cement slightly accumulates, making it more alkaline than superficial soils in forests and fields. An Ochroconis strain, designated as Group P, was found in city parks and was physiologically similar to the indoor species, O. humicola. Group P can use detergents as nutrients and grows under alkaline conditions. However, O. humicola was not found in the city parks of the Honshu and Kyushu Islands (Hamada and Abe, 2018).

If alkaline soil promotes the growth of Ochroconis strains in the parks, it can be assumed that many species of Ochroconis were distributed in limestone areas and immigrated to other alkaline environments. Moreover, some of them may be able to grow on media containing non-ion surfactants.

In a preliminary study, we collected the soils from 
regions outside and inside of limestone caves and isolated several Ochroconis strains. In this study, phylogenetic analysis, morphological observation, and culture examination, using media including detergents or others, were conducted on samples from various localities. Ochroconis strains from the soils of limestone areas were also compared with strains from indoors or city parks, by focusing on alkaline tolerance, heat resistance, and drought tolerance. Moreover, factors controlling the growth of Ochroconis strains under three different environmental conditions, namely indoors, in city parks, and in limestone areas, were also examined. The immigration process of Ochroconis strains from limestone areas to indoors or city parks was also discussed.

In this study, the genus Ochroconis was used in place of Scolecobasidium, according to previous reports (de Hoog et al., 2000; Samerpitak et al., 2014).

\section{MATERIALS AND METHODS}

\section{Collection of samples}

To isolate Ochroconis strains, we collected soil samples from limestone areas, including inside limestone caves. At each sampling site, about $30 \mathrm{~g}$ of superficial soil from the surface layer was collected at 6-12 spots, as previously described for sample collection from city parks (Hamada and Abe, 2018).

Approximately $2 \mathrm{~g}$ of collected soil was suspended in $100 \mathrm{~mL}$ of distilled water; the suspension was diluted 1:100 and 1:1,000 and then spread onto 1/4 potato dextrose agar (PDA). After incubation for 7-10 d at $25^{\circ} \mathrm{C}$, brown or light brown colonies resembling Ochroconis were isolated for identification. One Ochroconis strain, among two or more strains with similar features, was selected from each sampling site. In this study, about 50 Ochroconis strains were isolated from 26 of the 29 sampling sites in limestone areas (Table 1). Moreover, some strains with few conidia were eliminated from the list of collected samples, because examining their physiological features was difficult.

The $\mathrm{pH}$ of the soil samples $(10 \mathrm{~g})$ in which the fungi were detected was measured following a standard method (Hamada and Abe, 2018).

\section{Strains and DNA extractions}

The 42 Ochroconis strains used for this study, together with their localities, are listed in Table 1. Prior to the present study, all isolates were identified as Ochroconis at the genus level according to the characteristics of their colonies and conidia (de Hoog et al., 2000). After preculture, a small piece of agar with one colony was added in $1 \mathrm{~mL}$ of phosphate buffered saline (PBS) for DNA extraction. The DNA was extracted and purified using the DNeasy Blood \& Tissue kit (Qiagen
GmbH, Hilden, Germany) according to the manufacturer's instructions.

\section{Polymerase chain reaction (PCR) and phylogenetic analysis}

Previously, our study showed that the phylogenetic topologies reconstructed using the sequences of $18 \mathrm{~S}$ rDNA, 28S rDNA, tef1, or rbp2 were the same among Ochroconis spp. (Abe and Hamada, 2011). The $28 \mathrm{~S}$ rDNA locus was applied for the present analysis. A phylogenetic analysis was carried out using the MEGA7 software. The 28S rDNA sequences obtained were aligned with those from representative Ochroconis species. A phylogenetic tree was reconstructed using the neighbor-joining method with the p-distance algorithm. The reliability of the phylogram was tested with the bootstrap method using 1,000 replications. The 28S rDNA sequences obtained in this study are available in the International Nucleotide Sequence Database (GenBank/DDBJ]/EMBL) under accession numbers LC469356-LC469397.

\section{Morphological examination}

For each strain, the color, size, shape, wall structure, and number of cells comprising conidia in each colony were observed by a light microscope (ECLIPSE E600; Nikon, Tokyo, Japan), and by magnifying the images 1,000 times by oil immersion light microscopy (Leica, Germany).

\section{Growth of Ochroconis species on various media}

The 42 precultured outdoor strains were examined for their physiological characteristics, as described previously (Hamada and Abe, 2018). A $0.5 \mathrm{~mL}$ of the conidial suspension from each strain was plated uniformly on two culture plates containing media with different compositions (see below). All plates were incubated at $25 \pm$ $1{ }^{\circ} \mathrm{C}$ for $10-12 \mathrm{~d}$. The fungal count shown in Table 2 is presented as an average of the colony numbers on two plates.

The growth of Ochroconis strains was examined on media containing two surfactants: soap, sodium oleate (SO), or non-ion surfactant, polyoxyethylene- (9)-lauryl ether (AE). To prepare these media, SO or AE at $0.1 \%$ w/v was added to $15 \mathrm{~g} / \mathrm{L}$ of Bacto agar (Difco, USA).

Each strain was cultured on the alkaline 1/4 PDA medium to examine its tolerance to alkaline conditions. To adjust the $\mathrm{pH}$ value of the medium to an alkaline level, a modified version of the method reported by Nagai et al. (1998) was applied. Namely, $\mathrm{Na}_{2} \mathrm{CO}_{3}(3 \mathrm{~g})$ and $\mathrm{NaH}_{2} \mathrm{PO}_{4}(3 \mathrm{~g})$ were added to 1/4 PDA. The pH of 1/4 PDA was 6.6, whereas that of the modified (i.e., alkaline) 1/4 PDA was 9.7.

To examine the tolerance of the fungi to drought, each 
strain was cultured on dichloran glycerol (DG18) agar base (Oxoid, England) containing $31.5 \mathrm{~g} / \mathrm{L}$ and 220 $\mathrm{g} / \mathrm{L}$ glycerol, with the latter concentration being used to detect xerophilic fungi.

To examine the heat stress tolerance of fungi, conidial suspensions of each fungus were placed in water baths (Masuda; M-205) at $50 \pm 1{ }^{\circ} \mathrm{C}$ for $10 \mathrm{~min}$. After treatment, the suspensions were inoculated and cultured onto 1/4 PDA.

\section{RESULTS}

\section{Molecular characterization of the strains}

The 28S rDNA sequences were obtained from 42 strains of Ochroconis collected from limestone areas from Iwate Pref. (40N) to Okinawa Pref. (24N). Some strains were identified genetically by comparison with ones collected from indoors or city parks in previous studies (Hamada and Abe, 2018). As shown in Fig. 1, the two strains (NH2012 and NH754) from Okinawa Pref. were classified into O. humicola, which was predominantly found indoors. The eight strains isolated from the limestone areas and the predominant strains of Ochroconis (NH503) found in urban city parks were grouped together (park group: Group P). But Group $\mathrm{P}$ was more common in city parks, where 14 out of 24 Ochroconis strains were found. Moreover, three strains were identical to ones from city parks; NH552 was identified as $\mathrm{O}$. constricta, $\mathrm{NH} 236$ as $\mathrm{O}$. verruculosa, and $\mathrm{NH} 273$ as Ochroconis sp. $\mathrm{NH} 11772$. The 42 strains collected from the limestone areas varied more than strains from city parks.

The other 29 strains were not found in city parks. Some of them were identified as species reported previously (Samperpitak et al., 2009). Three strains of O. macrozamiae, three of O. cordanae, and two of $S$. excentricum were found. Moreover, one strain of O. lascauxensis, O. anellii, O. globalis, O. bacilliformis, and $O$. robusta was also found. The other 16 strains of Ochroconis species collected were genetically different from each other and were hence thought to be novel.

Ochroconis strains were found both inside and outside the caves in the limestone areas, although the fungal number found inside the caves was less than 1/10th of that found outside.

\section{Morphological characterization of the strains}

The conidia of two strains of isolated $O$. humicola were two-celled, pale brown, cylindrical-shaped, 8-9 $\mu \mathrm{m}$ in length, and smooth-walled or verruculose (Table 1). The conidia of eight strains of Group P were two-celled, pale brown, cylindrical-shaped, 7-9 $\mu \mathrm{m}$ in length, and verrucose or echinulate-walled.

The NH236 strain showed two-celled, oblong, and echinulate-walled conidia, and resembled those of $O$. verruculosa. Moreover, the conidia of NH552 were similar to those of $O$. constricta. The other strains, for example O. cordanae and O. macrozamiae, which were identified as species previously reported, were confirmed morphologically.

The $\mathrm{pH}$ of each soil sample from the limestone area was analyzed (Table 1). The $\mathrm{pH}$ ranged from 6.09 to 9.33. The average $\mathrm{pH}$ was 7.57 and was more alkaline than the $\mathrm{pH}$ of 6.89 found in city parks. The average $\mathrm{pH}$ inside the caves was 8.30 , relatively more alkaline than the $\mathrm{pH}$ of 7.37 found outside the caves.

\section{Growth differences among Ochroconis species}

Most of the isolated strains (36/42) grew on $0.1 \%$ SO medium, and the colony number for most strains (32/36) was $\geq 50 \%$ of those grown on $1 / 4$ PDA (control), although the size of the colonies was smaller than that on 1/4 PDA (Table 2).

Only 13 Ochroconis strains grew on the $0.1 \% \mathrm{AE}$ medium. Interestingly, two strains of $O$. humicola, four to eight strains of Group P, and one strain of $O$. constricta grew on the $0.1 \% \mathrm{AE}$ medium as well as strains from city parks or indoors. Otherwise, 6 to 31 other strains of Ochroconis grew on the $0.1 \% \mathrm{AE}$ medium; two strains of $O$. cordanae, and a strain of $O$. verruculosa grew on them, and 3 strains of Ochroconis sp., which was different in phylogenetic analysis, grew on them.

On the 1/4 PDA medium adjusted to $\mathrm{pH}$ 9.7, 34/42 isolated strains grew. All of the O. humicola and Group P strains grew on the alkaline medium. Moreover, all strains able to use $0.1 \%$ AE grew on the alkaline medium. The size of the colonies on alkaline medium was similar in 10 of 42 strains, compared to those growing on the control.

The drought tolerance of Ochroconis strains was compared. Some strains (14/42) of Ochroconis samples grew on the xerophilic medium (DG18), although the colony size for all these strains was smaller than colonies growing on the control medium. Moreover, seven strains, including $O$. humicola, $O$. constricta, $O$. cordanae, and $O$. verruculosa, growing on xerophilic medium also grew on the AE medium.

The heat tolerance of the strains was analyzed according to the incubation temperature (i.e., $50{ }^{\circ} \mathrm{C}$ ) (Table 2). More than half of the Ochroconis strains (25/42) could survive at $50{ }^{\circ} \mathrm{C}$, with 13 to 15 strains belonging to $\mathrm{O}$. humicola, Group P, O. cordanae, $\mathrm{O}$. constricta, and $O$. verruculosa, including strains growing on the AE medium. Most AE-positive strains (12/13) exhibited heat tolerance. In addition, strains growing on $0.1 \%$ AE media, including O. humicola and Group $P$ strains, showed similar physiological responses to drought and heat. 


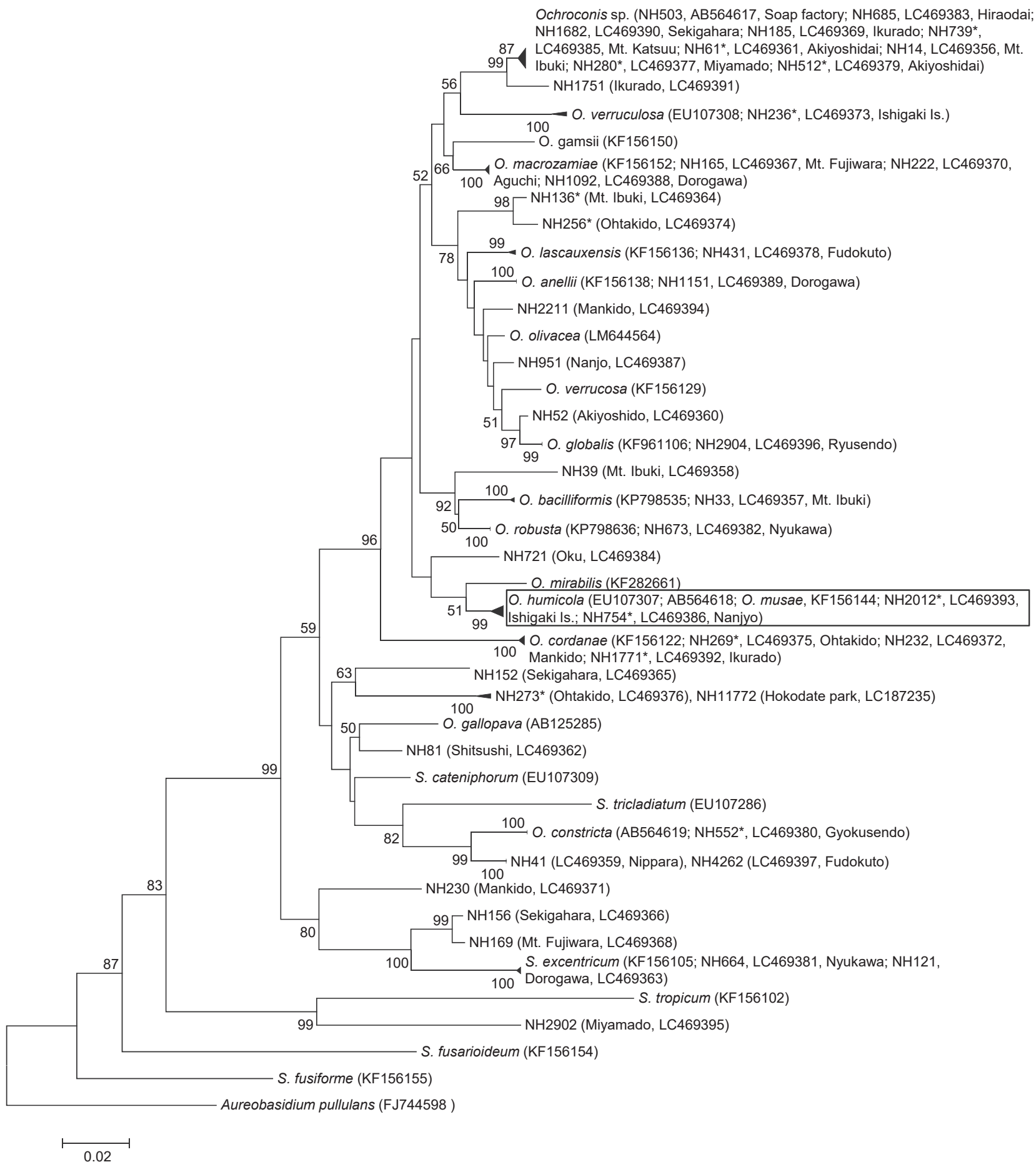

FIG. 1. Phylogenetic relationships of 42 Ochroconis strains collected from various localities of limestone areas compared to reference strains of Ochroconis species, as inferred from distance-based analysis of 28S rDNA sequences.

The strain number $(\mathrm{NH})$ and accession numbers are shown in parentheses, and the asterisk indicates a strain with the ability to use AE (non-ion surfactant) as a nutrient. Bootstrap support (>50\% for 1000 replicates) is shown at each node. 
TABLE 1. Fungal characteristics of Ochroconis collected from soil of the limestone area

\begin{tabular}{|c|c|c|c|c|c|c|c|c|c|c|c|c|c|c|}
\hline \multirow{2}{*}{$\begin{array}{l}\text { Sample } \\
\text { number }\end{array}$} & \multirow{2}{*}{$\begin{array}{c}\text { Accession } \\
\text { number }\end{array}$} & \multirow{2}{*}{ Species } & \multirow{2}{*}{ Group } & \multirow{2}{*}{ Locality } & \multirow{2}{*}{ Prefecture } & \multirow{2}{*}{ Latitude } & \multirow{2}{*}{ Altitude } & \multirow{2}{*}{ Caves } & \multirow{2}{*}{$\mathrm{pH}$} & \multicolumn{5}{|c|}{ Conidia } \\
\hline & & & & & & & & & & Color & Shape & Size & Cell & Wall \\
\hline 754 & LC469386 & O. humicola & & Nanjyo & Okinawa & 26 & 50 & outside & 7.20 & pale brown & cylindrical & 9 & 2 & smooth \\
\hline 2012 & LC469393 & O. humicola & & Ishigaki Is. & Okinawa & 24 & 10 & outside & 8.08 & pale brown & cylindrical & 8 & 2 & verruculose \\
\hline 552 & LC469380 & O. constricta & & Gyokusendo & Okinawa & 26 & 0 & inside & 8.04 & pale brown & cylindrical & 8 & 2 & verrucose \\
\hline 1151 & LC469389 & O. anellii & & Dorogawa & Nara & 34 & 850 & inside & 8.15 & pale brown & cylindrical & 15 & 4 & smooth \\
\hline 33 & LC469357 & O. bacilliformis & & Mt. Ibuki & Shiga & 35 & 1300 & outside & 7.17 & pale brown & cylindrical & 9 & 2 & smooth \\
\hline 269 & LC469375 & O. cordanae & & Ontakido & Gifu & 36 & 400 & outside & 6.99 & pale brown & cylindrical & 13 & $2-4$ & smooth \\
\hline 232 & LC469372 & O. cordanae & & Mankido & Okayama & 35 & 300 & outside & 8.04 & pale brown & cylindrical & 12 & $2-4$ & smooth \\
\hline 1771 & LC469392 & O. cordanae & & Ikurado & Okayama & 35 & 200 & outside & 8.43 & pale brown & cylindrical & 9 & 2 & smooth \\
\hline 664 & LC469381 & S. excentricum & & Nyukawa & Gifu & 36 & 900 & outside & 8.22 & pale brown & cylindrical & 12 & 2 & verrucose \\
\hline 121 & LC469363 & S. excentricum & & Dorogawa & Nara & 34 & 800 & outside & 7.12 & pale brown & cylindrical & 12 & 2 & smooth \\
\hline 2904 & LC469396 & O. globalis & & Ryusendo & Iwate & 40 & 10 & inside & 8.35 & pale brown & cylindrical & 10 & 2 & smooth \\
\hline 431 & LC469378 & O. lascauxensis & & Fudokutsu & Nara & 34 & 600 & inside & 7.97 & pale brown & cylindrical & 11 & 4 & verrucose \\
\hline 165 & LC469367 & O. macrozamiae & & Mt. Fujiwara & Mie & 35 & 650 & outside & 6.47 & pale brown & cylindrical & 6 & 2 & verrucose \\
\hline 222 & LC469370 & O. macrozamiae & & Aguchi & Okayama & 35 & 400 & inside & 7.81 & pale brown & cylindrical & 9 & 2 & verruculose \\
\hline 1092 & LC469388 & O. macrozamiae & & Dorogawa & Nara & 34 & 800 & outside & 8.36 & pale brown & cylindrical & 8 & 2 & verruculose \\
\hline 673 & LC469382 & O. robusta & & Nyukawa & Gifu & 36 & 900 & inside & 8.28 & pale brown & oblong & 7 & 2 & smooth \\
\hline 236 & LC469373 & O. verruculosa & & Ishigaki Is. & Okinawa & 24 & 10 & outside & 8.15 & pale brown & oblong & 8 & 2 & echinulate \\
\hline 280 & LC469377 & Ochroconis sp. & $\mathrm{P}$ & Miyamado & Gifu & 36 & 600 & outside & 6.64 & pale brown & cylindrical & 8 & 2 & echinulate \\
\hline 14 & LC469356 & Ochroconis sp. & P & Mt. Ibuki & Shiga & 35 & 900 & outside & 6.94 & pale brown & cylindrical & 8 & 2 & verrucose \\
\hline 1682 & LC469390 & Ochroconis sp. & $P$ & Sekigahara & Gifu & 35 & 200 & inside & 8.06 & pale brown & cylindrical & 9 & 2 & verrucose \\
\hline 185 & LC469369 & Ochroconis sp. & $\mathrm{P}$ & Ikurado & Okayama & 35 & 200 & inside & 9.33 & pale brown & cylindrical & 7 & 2 & verrucose \\
\hline 61 & LC469361 & Ochroconis sp. & $P$ & Akiyoshidai & Yamagichi & 34 & 300 & outside & 7.96 & pale brown & cylindrical & 8 & 2 & verrucose \\
\hline 512 & LC469379 & Ochroconis sp. & $P$ & Akiyoshidai & Yamagichi & 34 & 300 & outside & 7.79 & pale brown & cylindrical & 8 & 2 & echinulate \\
\hline 685 & LC469383 & Ochroconis sp. & $P$ & Hiraodai & Fukuoka & 34 & 400 & outside & 6.96 & pale brown & cylindrical & 9 & 2 & verrucose \\
\hline 739 & LC469385 & Ochroconis sp. & $P$ & Mt. Katsuu & Okinawa & 27 & 100 & outside & 7.15 & pale brown & cylindrical & 8 & 2 & verru \\
\hline 2902 & LC469395 & Ochroconis sp. & - & Miyamado & Gifu & 36 & 600 & outside & 6.96 & subhyaline & clavate & 11 & 2 & smooth \\
\hline 41 & LC469359 & Ochroconis sp. & - & Nippara & Tokyo & 36 & 800 & outside & 7.50 & pale brown & cylindrical & 7 & 2 & smooth \\
\hline 256 & LC469374 & Ochroconis sp. & - & Ohtakido & Gifu & 36 & 400 & inside & 8.70 & pale brown & cylindrical & 12 & 4 & verruculose \\
\hline 273 & LC469376 & Ochroconis sp. & - & Ohtakido & Gifu & 36 & 400 & outside & 6.09 & pale brown & clavate & 14 & 2 & smooth \\
\hline 81 & LC469362 & Ochroconis sp. & - & Shitsushi & Kyoto & 35 & 400 & outside & 6.61 & pale brown & cylindrical & 10 & 2 & verrucose \\
\hline 39 & LC469358 & Ochroconis sp. & - & Mt. Ibuki & Shiga & 35 & 1300 & outside & 7.06 & pale brown & cylindrical & 10 & 2 & smooth \\
\hline 136 & LC469364 & Ochroconis sp. & - & My. Ibuki & Shiga & 35 & 1300 & outside & 7.31 & pale brown & cylindrical & 9 & 2 & verrucose \\
\hline 156 & LC469366 & Ochroconis sp. & - & Sekigahara & Gifu & 35 & 200 & outside & 6.81 & pale brown & cylindrical & 9 & 2 & smooth \\
\hline 152 & LC469365 & Ochroconis sp. & - & Sekigahara & Gifu & 35 & 200 & outside & 7.70 & pale brown & cylindrical & 12 & $2-4$ & verrucose \\
\hline 169 & LC469368 & Ochroconis sp. & - & Mt. Fujiwara & Mie & 35 & 800 & outside & 7.30 & pale brown & clavate & 15 & 4 & smooth \\
\hline 230 & LC469371 & Ochroconis sp. & - & Mankido & Okayama & 35 & 300 & outside & 6.70 & pale brown & oblong & 7 & 2 & verruculose \\
\hline 2211 & LC469394 & Ochroconis sp. & - & Mankido & Okayama & 35 & 300 & outside & 7.69 & pale brown & cylindrical & 6 & 2 & verrucose \\
\hline 1751 & LC469391 & Ochroconis sp. & - & Ikurado & Okayama & 35 & 200 & outside & 7.68 & pale brown & cylindrical & 8 & 2 & verrucose \\
\hline 4262 & LC469397 & Ochroconis sp. & - & Fudokutsu & Nara & 34 & 600 & outside & 7.46 & pale brown & cylindrical & 8 & 2 & verruculose \\
\hline 52 & LC469360 & Ochroconis sp. & - & Akiyoshidai & Yamagichi & 34 & 300 & outside & 7.49 & pale brown & cylindrical & 7 & 2 & verrucose \\
\hline 721 & LC469384 & Ochroconis sp. & - & Oku & Okinawa & 27 & 30 & outside & 7.50 & pale brown & cylindrical & 9 & 2 & smooth \\
\hline 951 & LC469387 & Ochroconis sp. & - & Nanjyo & Okinawa & 26 & 30 & outside & 7.54 & pale brown & cylindrical & 7 & 2 & smooth \\
\hline
\end{tabular}

Sampling sites and characteristics of conidia were shown.

Two samples of $\mathrm{NH} 61$ and $\mathrm{NH} 512$ were collected at 2 sites separated aboout $1 \mathrm{~km}$ in Akiyoshidai. 
198

N. HAMADA ET AL.

TABLE 2. The growth of Ochroconis strains collected from soils of the limestone area cultured on the various media

\begin{tabular}{|c|c|c|c|c|c|c|c|c|c|c|c|c|c|c|}
\hline \multirow{2}{*}{$\begin{array}{l}\text { Sample } \\
\text { number }\end{array}$} & \multirow[b]{2}{*}{ Species } & \multirow[b]{2}{*}{ Group } & \multirow[b]{2}{*}{ Locality } & \multirow{2}{*}{$\begin{array}{l}\text { 1/4 PDA } \\
\text { colony } \\
\text { number }\end{array}$} & \multicolumn{2}{|c|}{$\mathrm{pH} 9.7$} & \multicolumn{2}{|c|}{$0.1 \% \mathrm{SO}$} & \multicolumn{2}{|c|}{$0.1 \% \mathrm{AE}$} & \multicolumn{2}{|c|}{ DG18 } & \multicolumn{2}{|c|}{$50^{\circ} \mathrm{C}^{1)}$} \\
\hline & & & & & size & $\begin{array}{l}\text { colony } \\
\text { number }\end{array}$ & size & $\begin{array}{l}\text { colony } \\
\text { number }\end{array}$ & size & $\begin{array}{l}\text { colony } \\
\text { number }\end{array}$ & size & $\begin{array}{l}\text { colony } \\
\text { number }\end{array}$ & size & $\begin{array}{l}\text { colony } \\
\text { number }\end{array}$ \\
\hline 754 & O. humicola & & Nanjyo & 81 & + & 56 & + & 58 & + & 10 & + & 55 & ++ & 25 \\
\hline 2012 & O. humicola & & Ishigaki Is. & 69 & ++ & 61 & + & 61 & + & 8 & + & 64 & ++ & 35 \\
\hline 552 & O. constricta & & Gyokusendo & 99 & ++ & 70 & + & 90 & + & 42 & + & 57 & + & 13 \\
\hline 1151 & O. anellii & & Dorogawa & 54 & + & 49 & + & 50 & - & 0 & - & 0 & + & 18 \\
\hline 33 & O. bacilliformis & & Mt. Ibuki & 91 & + & 42 & + & 49 & - & 0 & - & 0 & ++ & 9 \\
\hline 269 & O. cordanae & & Ohtakido & 88 & + & 84 & + & 77 & + & 46 & + & 80 & ++ & 16 \\
\hline 232 & O. cordanae & & Mankido & 92 & + & 62 & + & 40 & - & 0 & + & 64 & - & 0 \\
\hline 1771 & O. cordanae & & Ikurado & 82 & ++ & 85 & + & 80 & + & 72 & + & 39 & + & 21 \\
\hline 664 & S. excentricum & & Nyukawa & 88 & - & 0 & + & 65 & - & 0 & - & 0 & - & 0 \\
\hline 121 & S. excentricum & & Dorogawa & 75 & - & 0 & + & 34 & - & 0 & - & 0 & - & 0 \\
\hline 2904 & O. globalis & & Ryusendo & 59 & ++ & 60 & + & 42 & - & 0 & - & 0 & + & 43 \\
\hline 431 & O. lascauxensis & & Fudokutsu & 56 & ++ & 64 & + & 58 & - & 0 & - & 0 & ++ & 62 \\
\hline 165 & O. macrozamiae & & Mt. Fujiwara & 76 & + & 74 & + & 77 & - & 0 & + & 64 & - & 0 \\
\hline 222 & O. macrozamiae & & Aguchi & 56 & - & 0 & - & 0 & - & 0 & - & 0 & - & 0 \\
\hline 1092 & O. macrozamiae & & Dorogawa & 54 & + & 39 & + & 5 & - & 0 & - & 0 & - & 0 \\
\hline 673 & O. robusta & & Nyukawa & 71 & + & 39 & + & 37 & - & 0 & - & 0 & + & 1 \\
\hline 236 & O. verruculosa & & Ishigaki Is. & 67 & + & 56 & + & 67 & + & 44 & + & 57 & ++ & 17 \\
\hline 280 & Ochroconis sp. & $\mathrm{P}$ & Miyamado & 55 & ++ & 48 & + & 52 & + & 49 & - & 0 & ++ & 48 \\
\hline 14 & Ochroconis sp. & $\mathrm{P}$ & Mt. Ibuki & 70 & ++ & 71 & + & 78 & - & 0 & - & 0 & ++ & 76 \\
\hline 1682 & Ochroconis sp. & $\mathrm{P}$ & Sekigahara & 68 & + & 71 & + & 69 & - & 0 & + & 65 & + & 48 \\
\hline 185 & Ochroconis sp. & $\mathrm{P}$ & Ikurado & 76 & + & 30 & + & 34 & - & 0 & + & 75 & - & 0 \\
\hline 61 & Ochroconis sp. & $\mathrm{P}$ & Akiyoshidai & 61 & + & 52 & + & 54 & + & 43 & - & 0 & + & 58 \\
\hline 512 & Ochroconis sp. & $\mathrm{P}$ & Akiyoshidai & 86 & + & 88 & + & 90 & + & 82 & - & 0 & + & 80 \\
\hline 685 & Ochroconis sp. & $\mathrm{P}$ & Hiraodai & 98 & + & 102 & + & 74 & - & 0 & + & 88 & + & 64 \\
\hline 739 & Ochroconis sp. & $\mathrm{P}$ & Mt. Katsuu & 94 & + & 81 & + & 66 & + & 12 & - & 0 & ++ & 18 \\
\hline 2902 & Ochroconis sp. & - & Miyamado & 60 & + & 54 & - & 0 & - & 0 & - & 0 & - & 0 \\
\hline 41 & Ochroconis sp. & - & Nippara & 98 & + & 76 & + & 100 & - & 0 & - & 0 & - & 0 \\
\hline 256 & Ochroconis sp. & - & Ohtakido & 78 & + & 82 & + & 62 & + & 29 & + & 68 & + & 44 \\
\hline 273 & Ochroconis sp. & - & Ontakido & 98 & - & 0 & + & 70 & + & 63 & - & 0 & - & 0 \\
\hline 81 & Ochroconis sp. & - & Shitsushi & 82 & - & 0 & + & 56 & - & 0 & - & 0 & - & 0 \\
\hline 39 & Ochroconis sp. & - & Mt. Ibuki & 78 & - & 0 & - & 0 & - & 0 & - & 0 & - & 0 \\
\hline 136 & Ochroconis sp. & - & My. Ibuki & 50 & + & 51 & + & 38 & + & 38 & - & 0 & + & 36 \\
\hline 156 & Ochroconis sp. & - & Sekigahara & 76 & + & 72 & - & 0 & - & 0 & - & 0 & - & 0 \\
\hline 152 & Ochroconis sp. & - & Sekigahara & 66 & - & 0 & + & 67 & - & 0 & - & 0 & - & 0 \\
\hline 169 & Ochroconis sp. & - & Mt. Fujiwara & 54 & + & 16 & - & 0 & - & 0 & - & 0 & - & 0 \\
\hline 230 & Ochroconis sp. & - & Mankido & 57 & + & 50 & - & 0 & - & 0 & - & 0 & - & 0 \\
\hline 2211 & Ochroconis sp. & - & Mankido & 68 & + & 64 & + & 37 & - & 0 & - & 0 & + & 8 \\
\hline 1751 & Ochroconis sp. & - & Ikurado & 62 & + & 60 & + & 57 & - & 0 & - & 0 & + & 48 \\
\hline 4262 & Ochroconis sp. & - & Fudokutsu & 87 & - & 0 & + & 56 & - & 0 & - & 0 & + & 23 \\
\hline 52 & Ochroconis sp. & - & Akiyoshidai & 74 & ++ & 74 & + & 77 & - & 0 & + & 62 & + & 5 \\
\hline 721 & Ochroconis sp. & - & Oku & 69 & ++ & 55 & + & 43 & - & 0 & - & 0 & - & 0 \\
\hline 951 & Ochroconis sp. & - & Nanjyo & 87 & ++ & 52 & + & 42 & - & 0 & + & 76 & + & 8 \\
\hline
\end{tabular}

The count and the size of fungal colony on various culture condition were compared with that on 1/4 PDA medium.

The colony size was compared with that on 1/4 PDA, and assessed as follows: ++, same; +, smaller; -, undetectable.

1) Suspension of conidia was incubated at $50^{\circ} \mathrm{C}$ for $10 \mathrm{~min}$. 


\section{DISCUSSION}

A unique flora of higher plants and ferns, bryophytes, and lichens is said to be distributed in the limestone areas, although the limestone areas in Japan were covered with grasses, conifer, and deciduous trees (Shimizu, 1963). The alkaline soil seems to affect the fungal flora as well as plant flora. The average $\mathrm{pH}$ of soil in outdoor environments, including wild forests, was usually acidic, $\mathrm{pH}$ 5.24-5.77 (Hamada and Abe, 2018), but strains of Ochroconis isolated in this study were collected in soil from limestone with an average $\mathrm{pH}$ of 7.57 (Table 1). The Ochroconis strains were often found in the limestone areas as well as in city parks (pH 6.89 on average), and most fungi were able to grow on alkaline media and on the media with an added soap component. Thus, compared to general wild environments, the limestone areas seem to provide better conditions for many strains of Ochroconis.

However, conditions that are too alkaline, such as those inside limestone caves, repress fungal growth (Pitt and Hocking, 2009). Moreover, organic substances that can be used as nutrients are less abundant inside the caves rather than outside; thus, the number of fungi was lower in samples collected from inside the cave. However, the distribution of Ochroconis seems to be similar, regardless of the region of sample collection; thus, we supposed that the genus Ochroconis has generally become adapted to alkaline environments.

The microclimate of the limestone areas was thought to be more variable than that of city parks, because the limestone areas are variable geographically and covered with various plants. Moreover, the environments in city parks change easily with regard to temperature and humidity, and hence it is more difficult for fungi to survive in city parks than in limestone. Therefore, Ochroconis strains with various genetic and physiological characteristics were able to grow in limestones, although their $\mathrm{pH}$ is generally more alkaline than in city parks. Twenty-eight species were identified in 42 strains from limestones, compared with 8 species in 32 strains from city parks, or 3 species in 24 strains from indoors, as reported previously (Hamada and Abe, 2018). The diversity of Ochroconis was very high in limestones, although Ochroconis species are difficult to find in other areas than limestones. Thus, we assumed that many Ochroconis species originally distributed in limestones spread to city parks and indoor environments.

In a previous study (Hamada and Abe, 2018), three (O. constricta, Group P, and O. humicola) out of eight species of Ochroconis from city parks grew on media containing non-ion surfactants, and the ability of $O$. humicola to use surfactants was higher than that of other Ochroconis species. In this study, 8 out of 28 species collected in the limestone areas grew using non-ion surfactants as nutrients. Phylogenetic analysis showed that the characteristic of using non-ion surfactants was found randomly in many clusters. Thus, the ability to use non-ion surfactants as nutrients appears to be distributed throughout the genus of Ochroconis. The species using surfactants could be candidates for immigration to indoor environments, although only $\mathrm{O}$. humicola was found predominantly indoors.

Although other factors besides the ability to use non-ion surfactants were thought to affect propagation in the indoor environments, the ability to grow under alkaline conditions affected immigration in the previous study (Hamada and Abe, 2018). Moreover, heat tolerance and drought tolerance were found to be linked to the utilization of non-ion surfactants in this study (Table 2). Ochroconis humicola possesses all of these abilities, unlike other Ochroconis species.

In this study, we obtained many strains of Ochroconis from the limestone areas in the Honshu islands (farther north than $30 \mathrm{~N}$ ) as well as from urban city parks, as described previously (Hamada and Abe, 2018) but we could not find any $O$. humicola outside of these regions. However, in the southern islands, located farther south than $30 \mathrm{~N}, 0$. humicola was found for the first time in limestones in this study, as well as outdoors in two city parks, as described previously (Hamada and Abe, 2018). Namely, O. humicola is suggested to have been distributed originally in alkaline soils in sub-tropical regions.

Ochroconis humicola from the limestone areas spread to city parks and indoor environments, and then to indoor environments all over the world, including Asia, Europe, and USA. Subsequently, O. humicola became predominant in the indoor environments, with the characteristic of using detergents more effectively than other fungi. However, O. humicola from outdoor environments has not spread to the northern regions.

Ochroconis strains, which were not heat-tolerant or drought-tolerant, were predominantly found in the limestone areas, but not in city parks. This result suggests that the environmental conditions of limestones are generally milder and moister than those in city parks. In this study, the Group P strains of Ochroconis were also found in limestones, although the strains were found more commonly in the soils from city parks. Group P strains may have occurred originally in the limestone areas and then immigrated to the urban city parks with the dust of cement and seem to have adapted to hot and dry conditions. 


\section{ACKNOWLEDGEMENTS}

This study was supported by a grant from the Japan Society for the Promotion of Sciences to N. H. (Research Project Number 21500750). We wish to thank Dr. D. Sakuma for his helpful suggestions. We would like to thank Editage for English language editing.

\section{REFERENCES}

Abe, N., and Hamada, N. (2011) Molecular characterization and surfactant utilization of Scolecobasidium isolated from detergent-rich indoor environments. Biocontrol Science 16, 139-147.

de Hoog, G. S., Guarro, J., Gene, J., and Figueras, M. J. (2000) Hyphomycetes. Genus: Ochroconis. In Atlas of Clinical Fungi $2^{\text {nd }}$ edition (de Hoog, G. S., Guarro, J., Gene, J., and Figueras, M. J., ed.), pp.779-786, Centraalbureau voor Schimmelcultures, Utrecht.

Hamada, N. (2002) Fungal contamination in washing machines. Bokin Bobai, 30, 703-708. (in Japanese with English summary)
Hamada, N., and Abe, N. (2009) Physiological characteristics of 13 common fungal species in bathrooms. Mycoscience, 50, 421-429.

Hamada, N., and Abe, N. (2018) Molecular and biological differences among Ochroconis strains collected from indoor and outdoor environments. Biocontrol Science, 23, 187-198.

JSWE (Japan Society on Water Environment) (ed.) (2000) Non-ion surfactant and water environment. Gihoudo Press, Tokyo. (in Japanese)

Nagai, K., Suzuki, K., and Okada, G. (1998) Studies on the distribution of alkalophilic and alkali-tolerant soil fungi II: Fungal flora in two limestone caves in Japan. Mycoscience, 39, 293-298.

Pitt, J.I., and Hocking, A.D. (2009) Fungi and Food Spolilage ( $3^{\text {rd }}$ edition). Springer, NY.

Samerpitak, K., Van der Linde, E., Choi, H. -J., Gerrits van den Ende, A. H. G., Machouart, M., Gueidan C., and Hoog, G. S. (2014) Taxonomy of Ochroconis, genus including opportunistic pathogens on human and animals. Fungal Diversity 65, 89-126.

Shimizu, T. (1963) Studies on the limestone flora of Japan and Taiwan. Ph. D. Thesis. 